TOMASZ JUREK

Poznań

\title{
W SPRAWIE DATY KORONACJI WACŁAWA II NA KRÓLA POLSKIEGO
}

Gnieźnieńska koronacja Wacława na króla polskiego w 1300 r. to jedno z najważniejszych wydarzeń w politycznych dziejach średniowiecznej Polski. Źródła przekazały nam jednak tylko jej roczną datę. Żaden tekst nie podaje natomiast dokładnej daty dziennej. W historiografii przyjmowano długo datację letnią, jaką wprowadził František Palacký (wskazujący na lipiec-sierpień), a potem Josef Šusta (przyjmujący koniec sierpnia początek września) ${ }^{1}$. Nauce polskiej ustalenia te przyswoił Oswald Balzer ${ }^{2}$. Datowanie takie zostało jednak zakwestionowane przez Janusza Bieniaka ${ }^{3}$. Przesunął on koronację na końcowe miesiące roku, jako najprawdopodobniejszy wskazując listopad. Jego hipoteza oparta była na jednej tylko w gruncie rzeczy poszlace źródłowej. Mianowicie w dokumencie dygnitarzy pomorskich z 19 października 1300 r. mowa jest o Wacławie jako o „królu czeskim”, nie zaś jeszcze czeskim i polskim ${ }^{4}$. Znaczenie dodatkowe miał dokument księcia kujawskiego Przemysła dla cystersów z Byszewa z 7 grudnia 1300 r., wydany w Inowrocławiu bez udziału braci-współrządców ${ }^{5}$ - ci bowiem byli wtedy widocznie najpewniej na koronacji w Gnieźnie. Konstrukcja J. Bieniaka zyskała powszechną akceptację - i to

${ }^{1}$ F. Palacký, Dějiny národu českého v Čechách a v Moravě, t. 2, Praha 1939, s. 209; J. Šusta, Dvě knihy českých dějin, t. 1: Poslední Přemyslovci a jejich dědictví 1300-1308, Praha 1926, s. 319; idem, České dějiny, t. 2, cz. 1: Soumrak Přemyslovců a jejich dědictví, Praha 1935 , s. 567.

2 O. Balzer, Królestwo Polskie 1295-1370, t. 1, Lwów 1919, s. 401.

${ }^{3}$ J. Bieniak, Wielkopolska, Kujawy, ziemie łęczycka i sieradzka wobec problemu zjednoczenia państwowego w latach 1300-1306, Toruń 1969, s. 133-134 (wyd. 2, Wodzisław Śląski 2011, s. 108-109).

${ }^{4}$ Pommerellisches Urkundenbuch, wyd. M. Perlbach, Danzig 1882, nr 592.

${ }^{5}$ KDW II, nr 833. 
zarówno w literaturze polskiej, jak i czeskiej. Również autor niniejszych uwag wielokrotnie przyjmował jesienne datowanie koronacji. Czy jednak przesunięcie tradycyjnej datacji było słuszne? Czeski badacz Libor Jan, zajmujący się wiele czasami Wacława ${ }^{6}$, a obecnie przygotowujący pełną biografię tego władcy, nabrał poważnych wątpliwości. „Przedstawione rozwiązanie można by uważać za wysoce prawdopodobne, gdyby... Gdyby nie wkradło się pytanie: Czy koronacja Wacława nie odbyła się jednak kiedy indziej?"'.

L. Jan wskazuje przede wszystkim na panujący w kancelarii Wacława, podobnie jak u wielu innych monarchów, zwyczaj liczenia lat panowania, rachowanych oczywiście od dnia koronacji. Możemy w każdym razie odwołać się do niemałej liczby świadectw źródłowych. Pokazują one, że polska koronacja musiała dokonać się jednak przed listopadem 1300 r. Najważniejszych jest kilka dokumentów z 1301 r. - te z 29 lipca i 30 sierpnia podają jeszcze w datacji pierwszy rok, ten z 14 września natomiast już drugi rok polskich rządów króla Wacława ${ }^{8}$. Zmiana rachuby lat dokonywała się zatem między 30 sierpnia a 14 września. W tym też przedziale czasu musiała mieścić się koronacja roku 1300. Ponieważ powinna była mieć miejsce w ważne święto, mamy do wyboru niedziele 4 i 11 września lub też dzień Narodzenia Najświętszej Marii Panny 8 września (wypadający wtedy w czwartek). Miarodajność informacji czerpanych z formuł datacyjnych ostrożny autor sprawdził jeszcze na podstawie dużo obfitszego materiału dotyczącego rachuby rządów czeskich Wacława II. Wynika z niego, że zmiana liczby lat dokonywała się między 17 a 30 maja - ale wiemy, że koronacja na króla czeskiego odbyła się rzeczywiście 2 czerwca $1297 \mathrm{r}$. Wbrew pozorom nie ma tu jednak sprzeczności. Chodziło bowiem o Zesłanie Ducha Świętego, święto ruchome, a kanceliści liczyli najpewniej podług kalendarza kościelnego (i zmieniali rachubę lat w kolejne święto, które mogło wypadać także przed 2 czerwca).

Ustalenia L. Jana wydają się trudne do podważenia. Przeciwstawiają bowiem poszlakowej konstrukcji J. Bieniaka twardy konkret źródłowy. W dodatku, czego czeski autor nie zauważył, część tej konstrukcji straciła już aktualność. Chodzi mianowicie o argument wyprowadzony z doku-

${ }^{6}$ Tymczasem zob. L. Jan, Václav II. a struktury panovnické moci, Brno 2006.

${ }^{7}$ L. Jan, Znovu k datu hnězdenské korunovace krále Václava II., „Časopis Matice moravské” 131, 2012, s. 129-134; cytat ze s.131: „Uvedené řešení by byb možně nepochybné považovat za vysoce pravděpodobné, kdyby... kdyby se nevkrádla otázka: Neodehrála se Václavova herunovace prěce jenom jindy?".

${ }^{8}$ Regesta diplomatica nec non epistolaria Bohemiae et Moraviae, t. 2, wyd. J. Emler, Pragae 1882, nr 1890 (29 VII), 1894 (14 IX); J. Bistřický, F. Spurný, L. Václavek, M. Zemek, Moravské a slezské listiny lichtenštejnského archívu ve Vaduzu, t. 1, Brno 1991, nr 24 (30 sierpnia). 
mentu księcia Przemysła inowrocławskiego. Znalazł się bowiem wystawiony tego samego dnia 7 grudnia 1300 r. w Inowrocławiu w tej samej sprawie dokument jego brata Leszka ${ }^{9}$. Wszelkie domysły o znaczeniu absencji braci, bawiących jakoby w Gnieźnie, tracą więc rację bytu.

Szkoda może tylko, że L. Jan zapomniał w swym studium odnotować, iż cały jego wywód biegnie w zasadzie tym samym tropem,jaki przeszedł już kiedyś J. Šusta, który swe ustalenia również oparł na rachubie lat królewskich rządów Wacława ${ }^{10}$. Zdaje się, że podobnym tokiem myślowym poszedł też jeszcze wcześniej Palacký. Teraz otrzymaliśmy pewne nowe uściślenia (Šusta bowiem nie znał jeszcze dokumentu z 30 sierpnia 1301 r.) i ciekawe spostrzeżenia. Cenny jest w każdym razie sam powrót do niesłusznie, jak się okazuje, zarzuconych ustaleń poprzedników. Zmiana datowania koronacji ma też pewne znaczenie dla oceny ogólnej sytuacji politycznej. Ekspedycja Wacława II do Polski okazuje się krótsza, niż ostatnio sądzono. Tak więc, jak pisze L. Jan, „szło o bardzo szybką i mało kłopotliwą wyprawę"11.

${ }^{9}$ Trzynaście nie drukowanych oryginałów pergaminowych Archiwum Diec. we Włocławku z lat 1300-1400, wyd. S. Librowski, „Archiwa, Biblioteki i Muzea Kościelne” 1987, 55, s. $133, \mathrm{nr} 1$.

${ }^{10}$ „Kdy došlo ke korunovaci té, na den sice nevíme, ale podle datování panovnických let polských v pozdějších listinách Václavových jest zjevno, že se tak stalo v posledních dnech měsíce srpna 1300”, J. Šusta, Dvě knihy českých dějin, t. 1, s. 319.

11 „Šlo o poměrně rychlé a málo problematické tažení”, L. Jan, Znovu k datu, s. 134. 